Thorax (1964), 19, 79

\title{
Diffuse interstitial pulmonary fibrosis in patients with a positive sheep cell agglutination test
}

\author{
T. B. STRETTON AND J. T. LEEMING ${ }^{1}$ \\ From the Manchester Royal Infirmary
}

In 1944 Hamman and Rich described an acute form of diffuse interstitial pulmonary fibrosis in four patients who died within six months of the onset of symptoms. Many cases with a similar syndrome have since been reported. The majority of these, however, have run a more chronic course and the outcome has not always been fatal. The disorder has been fully reviewed by Rubin and Lubliner (1957) and Scadding (1960) ; its aetiology remains unknown. A number of patients with rheumatoid disease have had diffuse pulmonary fibrosis indistinguishable from the idiopathic variety (Ellman and Ball, 1948 ; Rubin and Lubliner, 1957; Smith and Rothermich, 1957 ; Scadding, 1960 ; Ognibene, 1960 ; Cudkowicz, Madoff, and Abelmann, 1961). These patients have all had overt arthritis, except for one of the patients described by Ognibene (1960); in this instance there was diffuse pulmonary fibrosis and the sheep cell agglutination test (S.C.A.T.) was positive but there was no gross arthritis, a diagnosis of anarthritic rheumatoid disease (Bagratuni, 1956) being made. We report here two further similar cases.

\section{CASE REPORTS}

CASE 1 A woman aged 45 was admitted in May 1960. For seven years she had suffered from increasingly severe breathlessness on exertion and for five years she had had a dry cough which recently had become productive of white, mucoid sputum. This illness was accompanied by general tiredness and lassitude. During the two years before her admission she had been receiving digitalis and occasional chlorothiazide from her general practitioner for the treatment of ankle swelling; the swelling improved but there was no change in the increasing breathlessness.

On examination there was gross finger clubbing and slight central cyanosis. She was in sinus rhythm, the blood pressure was $115 / 80 \mathrm{~mm}$. $\mathrm{Hg}$ and there was no cardiac abnormality; the venous pressure was normal. Coarse crepitations were audible over all areas of the lungs. The liver edge was palpable just

1 Present address: Bolton District General Hospital, Lancashire below the right costal margin. No abnormalities were found in the other systems.

Investigations The chest radiograph (Fig. 1) showed changes in the lungs typical of gross, widespread fibrosis with slight honeycombing in the lower zones. Serial radiographs had been taken at a chest clinic during the previous seven years and these were available for comparison. They revealed that the fibrosis had steadily increased in extent and severity over the years.

The patient's vital capacity was 0.95 litre, $27 \%$ of her predicted vital capacity of 3.55 litres. The one second forced expiratory volume (F.E.V.1) was 0.9 litre, giving a normal F.E.V.1 to vital capacity ratio $(95 \%)$.

The sputum contained normal upper respiratory tract flora and a beta-haemolytic streptococcus.

The S.C.A.T. was positive at a titre of $1 / 2048$.

The serum albumin was $2.5 \mathrm{~g} . / 100 \mathrm{ml}$. and the globulin $6.8 \mathrm{~g} . / 100 \mathrm{ml}$. Electrophoresis revealed a marked increase in the gamma-globulin, and there were no abnormal protein bands. The Sia test was positive ; there was no cryoglobulin. Serum bilirubin was $0.3 \mathrm{mg} . / 100 \mathrm{ml}$. ; thymol turbidity 25 units, zinc sulphate turbidity 44 units, and the alkaline phosphatase 63 King-Armstrong units $/ 100 \mathrm{ml}$. Serum glutamic-oxaloacetic transaminase was 52 units/100 $\mathrm{ml}$. and the serum glutamic-pyruvate transaminase was 66 units $/ 100 \mathrm{ml}$. The prothrombin activity was $80 \%$ of normal but rose to $100 \%$ after the administration of vitamin $K_{1}$. A bromsulphthalein test revealed $19 \%$ retention at 45 minutes.

A liver biopsy revealed granulomatous foci in the portal tracts ; these foci consisted of endothelioid cells, lymphocytes, occasional plasma cells, and polymorph leucocytes.

The haemoglobin (Hb) was $11.8 \mathrm{~g} . / 100 \mathrm{ml} .(80 \%)$. The total white cell count (W.B.C.) was $9,000 /$ c.mm. ; of these $60 \%$ were polymorphs, $33 \%$ lymphocytes, $3 \%$ mononuclears, and $4 \%$ eosinophils. Lupus erythematosus (L.E.) cells were not found. The erythrocyte sedimentation rate (E.S.R.) was $52 \mathrm{~mm}$. in one hour (Wintrobe). The Mantoux test was positive $1 / 100$. A Kveim test was negative.

Serum sodium was 140 , potassium 5.4 , chloride 92 , and plasma bicarbonate $27 \mathrm{mEq} / \mathrm{l}$. The blood urea was $26 \mathrm{mg} . / 100 \mathrm{ml}$. Serum calcium was 9.3 and phosphorus $3.6 \mathrm{mg} . / 100 \mathrm{ml}$. 


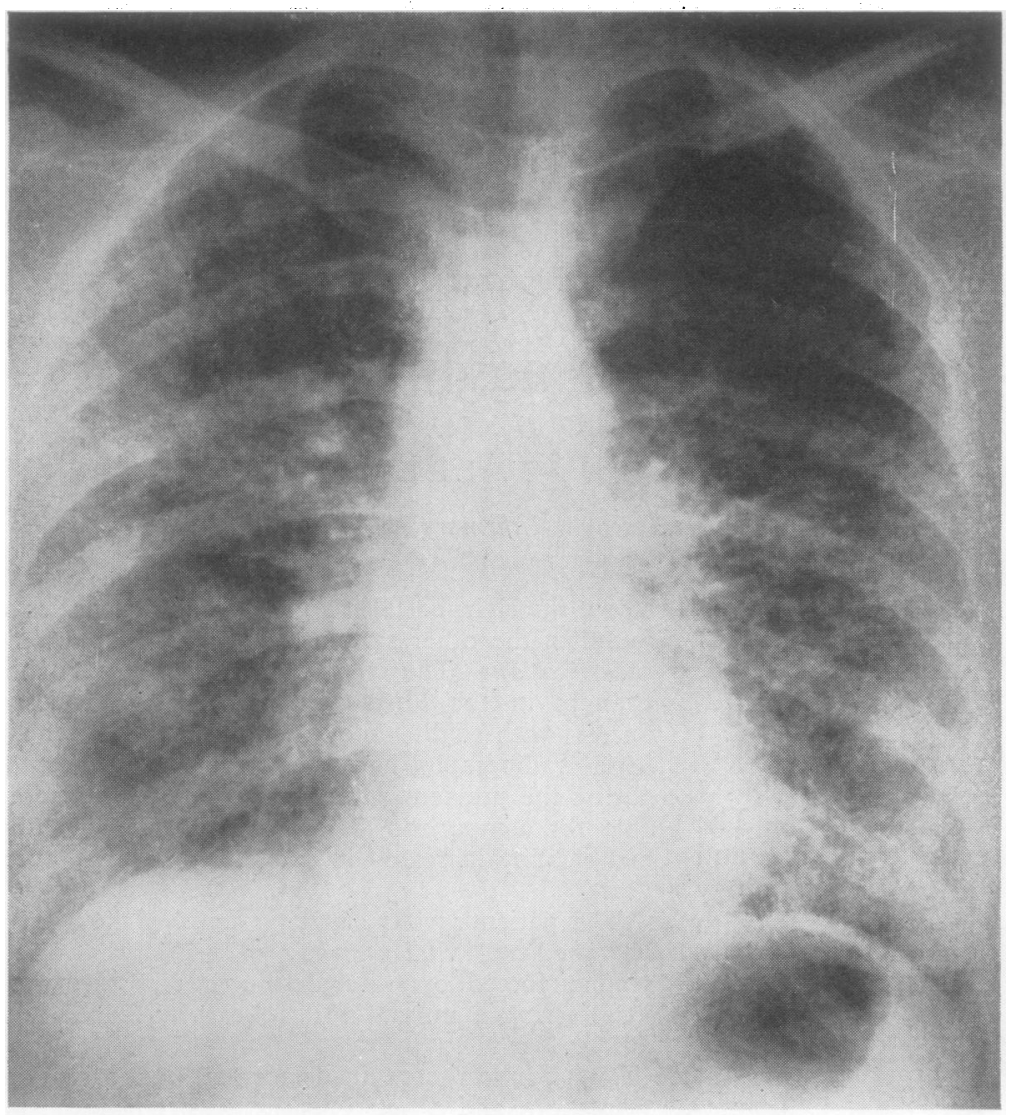

FIG. 1a

FIG. 1. Case 1. (a) Chest radiograph; (b) enlarged view of the left lower zone of the chest radiograph to show in detail the pulmonary abnormality. 
An electrocardiogram was normal apart from digitalis effect.

Treatment and subsequent investigations In view of the steady deterioration over the years, both symptomatically and radiologically, corticosteroid therapy was begun: prednisone was given in a dose of $10 \mathrm{mg}$. twice daily and has been continued up to the present time. Digitalis was continued and she has had occasional courses of tetracycline for intercurrent pulmonary infections. No change has occurred in the patient's condition during the two years of prednisone therapy although the amount of pulmonary fibrosis appears radiologically to have increased slightly.

In December 1961 the results of further pulmonary function tests were as follows: the vital capacity was 1.08 litres $(30 \%$ of the predicted value) and the F.E.V.1 was 0.9 litre $(83 \%$ of the measured vital capacity). The arterial $\mathrm{PcO}_{2}$ (determined by the method of Campbell and Howell, 1960) was $40 \mathrm{~mm}$. Hg.

Cardiac catheterization was performed in view of the suggestion from the history that the patient had previously been in congestive cardiac failure. (If this were so it was felt that there must be pulmonary hypertension although this was not manifest clinically. Because of the prognostic importance direct estimation of the pulmonary arterial pressure was thought to be desirable.) By the steady state Fick method the cardiac output was $3.59 \mathrm{1} . / \mathrm{min}$. at rest and $5.32 \mathrm{l} . / \mathrm{min}$. on exercise with an oxygen consumption of $244 \mathrm{ml} . / \mathrm{min}$. and $343 \mathrm{ml} . / \mathrm{min}$. respectively. The arterial and mixed venous oxygen saturations were $81 \%$ and $40 \%$ at rest and $81 \%$ and $41 \%$ on exercise. The mean pulmonary artery pressure at rest was $14 \mathrm{~mm}$. $\mathrm{Hg}$ and on exercise it was $16 \mathrm{~mm}$. $\mathrm{Hg}$.

The liver function tests have been repeated on numerous occasions. The pattern of abnormality has not changed: the serum albumin has varied from $2 \cdot 3$ to $3.6 \mathrm{~g} . / 100 \mathrm{ml}$. ; globulin 5.8 to $6.8 \mathrm{~g} . / 100 \mathrm{ml}$.; thymol turbidity 15 to 25 units ; zinc sulphate turbidity 44 to 63 units ; alkaline phosphatase 58 to 86 units/ $100 \mathrm{ml}$.; the serum bilirubin has been consistently normal.

CASE 2 A woman aged 61 was admitted in November 1960. She had been perfectly well until 10 months previously when she became increasingly breathless, at first on exertion but later also at rest. For four months she had had a dry, irritant cough, productive of a little white, frothy sputum. During this time she noticed that the fingers were becoming clubbed. On admission she was desperately breathless with a respiratory frequency of about $40 /$ minute. There was central cyanosis. The slightest exertion in bed, such as sitting forwards unaided whilst her back was examined, produced the most intense dyspnoea and increased the degree of cyanosis. These symptoms disappeared when she was given oxygen to breathe. Clubbing of the fingers and toes was marked. She had a sinus tachycardia of $100 /$ minute; the blood pressure was $110 / 70 \mathrm{~mm}$. $\mathrm{Hg}$. The cardiac impulse was normal ; there was a systolic ejection click and a mid-systolic murmur in the pulmonary area. The jugular venous pressure was $4 \mathrm{~cm}$. above the sternal angle and there was a trace of sacral oedema. Showers of crepitations were heard over all areas of the lungs. No other abnormalities were found.

Investigations Chest radiographs showed widespread changes in both lungs consistent with diffuse interstitial fibrosis together with some honeycombing. (The appearances were almost identical with those in case 1.)

The sputum yielded a mixed growth of organisms with a predominant growth of Staphylococcus saprophyticus.

The S.C.A.T. was positive at a titre of $1 / 256$.

The serum albumin was $3.3 \mathrm{~g} . / 100 \mathrm{ml}$., the globulin was $4.4 \mathrm{~g} . / 100 \mathrm{ml}$., bilirubin $0.8 \mathrm{mg} . / 100 \mathrm{ml}$., thymol turbidity 6.2 units, and the alkaline phosphatase was 6.0 King-Armstrong units $/ 100 \mathrm{ml}$. The blood urea was $55 \mathrm{mg}$. $/ 100 \mathrm{ml}$. Serum sodium was 143 , potassium 4.8 , chloride 92, and the plasma bicarbonate 34 $\mathrm{mEq} /$ litre.

The $\mathrm{Hb}$ was $16.6 \mathrm{~g} . / 100 \mathrm{ml}$. (114\%). The total W.B.C. was $13,400 /$ c.mm. (77\% polymorphs; $16 \%$ lymphocytes ; 7\% monocytes). No L.E. cells were found. The E.S.R. was $15 \mathrm{~mm}$. in one hour (Wintrobe).

An electrocardiogram demonstrated the presence of left bundle branch block.

Treatment and subsequent investigations Continuous oxygen therapy was given. Prednisone was commenced at a total daily dose of $60 \mathrm{mg}$. Antibiotics were administered. She was also given digitalis and diuretics. Her condition slowly improved so that in three weeks she was comfortable without the added oxygen. Serial radiographs, however, showed no change in the pulmonary fibrosis. Left bundle branch block persisted. The blood urea fell to $30 \mathrm{mg} . / 100 \mathrm{ml}$. and the plasma bicarbonate fell to $30 \mathrm{mEq} / \mathrm{l}$. The serum globulin fell to $3.2 \mathrm{~g} . / 100 \mathrm{ml}$. and the thymol turbidity to 2 units.

The vital capacity three weeks after admission was 1.21 litres, $37 \%$ of her predicted vital capacity (3.3 litres). The F.E.V.1 was 0.86 litre, giving a ratio of F.E.V.1 to vital capacity of $71 \%$. At this time the estimated arterial $\mathrm{PcO}_{2}$ was $42 \mathrm{~mm}$. Hg. Five weeks later the vital capacity had increased to 1.39 litres (42\% of the predicted value), and the F.E.V.1 was 1.24 litres (giving an $89 \%$ F.E.V.1 to vital capacity ratio).

Cardiac catheterization was performed two months after admission, when there was clinical improvement, for the same reasons as in the first patient. The mean pulmonary arterial pressure was $18 \mathrm{~mm}$. $\mathrm{Hg}$. The arterial blood was $83 \%$ saturated and the mixed venous blood was $56 \%$. The oxygen uptake at rest was $220 \mathrm{ml} . / \mathrm{min}$. and the cardiac output was 4.67 litres/min. Exercise studies were not feasible.

The initial improvement on treatment was maintained apart from an attack of supraventricular tachycardia, and the patient was discharged home five months after her admission. At this time she was able to sit out of bed and could walk short distances 
without gross dyspnoea. Two weeks later, however, her condition abruptly deteriorated and she died suddenly at home.

A necropsy was performed by Dr. G. Greville Williams. The main abnormalities were limited to the lungs. The central parts of these appeared normal to the naked eye but the peripheral halves were composed of a mass of smooth-walled cavities 1 to 1.5 $\mathrm{mm}$. in diameter. Histologically, in the less affected areas there was patchy fibrosis of the alveolar septa. The cysts (Fig. 2) mostly had no epithelial lining and were surrounded by a mixture of collagen and smooth muscle. There were a few lymphocytes and rather more plasma cells in the interstitial tissue with occasional cholesterol or fat-containing giant cells. A superimposed mild acute inflammation was seen. The overall picture was considered to be one of honeycomb lung, as described by Heppleston (1956). Skin and subcutaneous tissue from the elbows and hee's and the metacarpo-phalangeal joint of the right index finger were taken for histological study by Dr. J. Ball. There were no gross macroscopical changes in these regions but microscopically there was evidence of tissue damage. There was some fibrous thickening of the olecranon bursa of one elbow. At all sites there was hyaline fibrosis of the subcutaneous nerves with

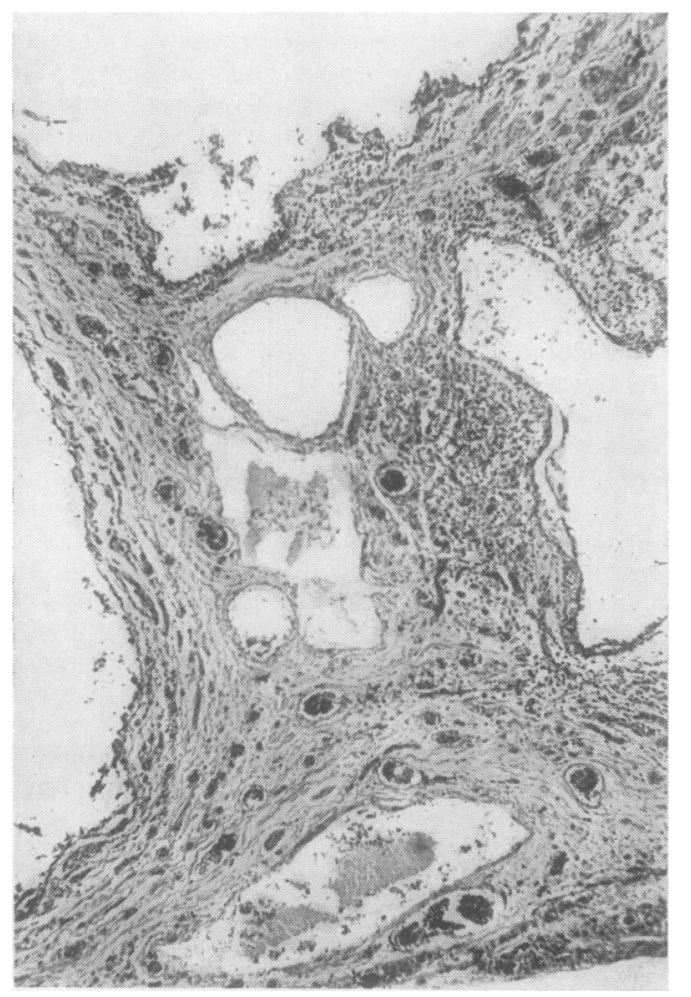

FIG. 2. Case 2. Low-power view of a section of the lung $(\times 180)$. loss of myelin and axons; this was thought to be $\overrightarrow{\vec{\rho}}$ related to the obliterative endarterial fibrosis which was a feature of many of the small arteries in the subcutaneous tissues. No active arthritis was found $\frac{\bar{m}}{\omega}$ though there was evidence of an old, healed, minor erosive arthropathy.

No significant abnormalities were found in other organs.

COMMENT Both these patients had restrictive $\overrightarrow{\vec{\omega}}$ pulmonary disease with normal alveolar ventila- $\stackrel{\circ}{\circ}$ tion $\left(\mathrm{PCO}_{2}\right.$ of 40 and $42 \mathrm{~mm}$. $\left.\mathrm{Hg}\right)$ and arterial unsaturation $(81 \%$ and $83 \%$ respectively $)$ breathing room air at rest. In the first patient the arterial saturation did not fall further on exercise, $\vec{\nabla}$ suggesting that this was due not to a limitation in diffusion but to a venous to arterial shunt (of $\stackrel{\circ}{\mathcal{}}$ some $30 \%$ of the cardiac output). Exercise studies $\vec{C}$ could not be done in the second patient but clinical examination showed that the slightest exertion whilst breathing room air caused further brisk arterial unsaturation and intense dyspnoea $; \vec{\varphi}$ these observations suggested that the patient had $\underset{\perp}{\Phi}$ a critical defect of gaseous diffusion. A surprising finding in both patients in the face of sucho extensive pulmonary fibrosis was the normal pulmonary arterial pressure and vascular resistance.

\section{DISCUSSION}

Oswald and Parkinson (1949) were the first authors to emphasize that honeycomb lungs occur in various diseases in which there is diffuse interstitial pulmonary infiltration. In six of their patients there was an associated disorder such as tuberous $\underset{\times}{\mathscr{Q}}$ sclerosis, xanthomatosis, biliary cirrhosis or $\overline{-}$ pituitary disease. In the other 10 cases no such 3 . recognizable disease was noted and, where histo- $\delta$ logical examination was carried out, extensive interstitial pulmonary fibrosis was found.을 Heppleston (1956), in an extensive study of the pathology of honeycomb lung, considered that the essential abnormality was an obliteration of the respiratory or non-respiratory bronchioles. He suggested that neighbouring unaffected bronchioles $N$ then underwent compensatory enlargement to form the cystic spaces. In the majority of his cases the obliterative process was a non-specific, interstitial fibrosis though in some a recognizable granulomatosis was seen. Heppleston concluded $\stackrel{\oplus}{\sim}$ that honeycomb lung was, in most instances, the result of patchy, interstitial fibrosis. The distinction between the two conditions is probably, therefore, $\stackrel{\mathbb{Q}}{\mathbb{Q}}$ somewhat artificial and, as shown by our case $2, \frac{\mathrm{\Phi}}{\mathrm{D}}$ radiological differentiation may be quite $\frac{0}{0}$ impossible. 
The aetiology of diffuse interstitial fibrosis of the lungs is often obscure (Scadding, 1960) but it has been found in association with a variety of diseases, including the connective tissue disorders (Rubin and Lubliner, 1957). It has been found in a number of patients with rheumatoid disease (Ellman and Ball, 1948 ; Rubin and Lubliner, 1957 ; Smith and Rothermich, 1957 ; Scadding, 1960 ; Ognibene, 1960 ; Cudkowicz et al., 1961). Honeycomb lung (sic) has also been found in rheumatoid patients (Hart and Mackenzie, 1955 ; Dixon and Ball, 1957 ; Brinkman and Chaikof, 1959). Other pulmonary disorders occur in rheumatoid disease: these include pleural effusions (Emerson, 1956; Mason and Steinberg, 1958; Horler and Thompson, 1959; Ward, 1961), rheumatoid nodules in the pleura or lung parenchyma (Christie, 1954 ; Gresham and Kellaway, 1958), Caplan's syndrome (Caplan, 1953), and a pulmonary arteritis (Price and Skelton, 1956 ; Gardner, Duthie, Macleod, and Allen, 1957). Of considerable interest is the occurrence of certain of these pulmonary disorders before the onset of the arthritis; this has been described in pleural effusions (Horler and Thompson, 1959) and in Caplan's syndrome where the development of pulmonary nodules has been known to antedate the onset of arthritis by up to 10 years (Caplan, 1959).

The presence of the positive S.C.A.T. in the two patients described here raised the possibility that each had a diffuse connective tissue disorder, the chief manifestation of which was the pulmonary abnormality. This possibility was strengthened in the first patient by the discovery of liver lesions although the exact nature of these was obscure. Similar lesions have been seen previously by one of us in a patient referred to by Scadding (1960) but in this patient the S.C.A.T. was negative (Scadding, personal communication, 1961). Furthermore, each patient was seen by Professor J. H. Kellgren who found evidence of minor abnormalities in the locomotor systems though at no time were there any symptoms referable to the joints. Finally, in the second patient, histological examination of tissue from the elbows and heels revealed evidence of tissue damage with obliterative endarterial fibrosis in many of the small subcutaneous arteries. Although there was no active arthritis, suggestive evidence of an old, minor, erosive arthropathy was found.

One similar case has been reported by Ognibene (1960): the patient was a 67-year-old woman who developed histologically proven diffuse interstitial fibrosis of the lungs and had a positive S.C.A.T. without arthritis ; she had, however, had arthralgia and muscle pains for a year before the onset of her pulmonary symptoms.

Kellgren and Ball (1959) have shown that the S.C.A.T. is most constantly positive in rheumatoid disease though it is sometimes positive in other connective tissue diseases: in systemic lupus erythematosus and scleroderma positive titres were found when articular or peripheral vascular lesions (or both) were prominent ; in polyarteritis nodosa Kellgren and Ball found that the S.C.A.T. was only positive when the polyarteritis developed as a complication of severe rheumatoid arthritis. In population studies Ball and Lawrence (1961) found that 1.6 to $5.4 \%$ of random samples of rural and urban communities had a positive S.C.A.T.; of these, only $20 \%$ had evidence of rheumatoid arthritis according to the criteria of the American Rheumatism Association (1959). But the incidence of rheumatoid arthritis rose sharply in subjects with S.C.A.T. titres greater than 1 in 16: in those with titres of 1 in 256 or more the incidence was $70 \%$. Furthermore, in a five-year follow-up of a selected urban group, of seven subjects who originally had a positive S.C.A.T. but no joint disease, two had in the meantime developed rheumatoid arthritis. The S.C.A.T. was studied by Ball (1955) in a group of South Wales coal-miners (with rheumatoid arthritis) investigated by Miall (1955). He found that the incidence of a positive S.C.A.T. and the titre of the tests were higher in subjects with progressive massive fibrosis or Caplan's syndrome than in those with simple pneumoconiosis or a normal chest radiograph. This difference could not be explained by differences in the severity or duration of the arthritis and was clearly related in some unknown way to the lung lesion. It seems quite possible, therefore, that the positive S.C.A.T.s in our patients were indicative of the presence of rheumatoid disease despite the absence of joint symptoms.

The present cases, together with that reported by Ognibene (1960), support the hypothesis that diffuse interstitial pulmonary fibrosis may occasionally be due to rheumatoid disease despite the absence of arthritis. We suggest that all such patients are screened by means of the S.C.A.T. to determine the frequency with which rheumatoid disease occurs in what may otherwise appear to be an idiopathic disorder.

\section{SUMMARY}

Two patients with severe diffuse interstitial pulmonary fibrosis are described. Each had a positive S.C.A.T. but neither had any symptoms 
referable to the joints. Evidence is presented that these patients had a connective tissue disorder, possibly rheumatoid disease, despite the absence of arthritis.

We wish to thank Dr. C. S. D. Don and Dr. A. Morgan Jones for permission to publish details of these patients. We are also indebted to Professor J. $\mathbf{H}$. Kellgren and Dr. E. G. Wade for advice, and to Dr. J. Ball and Dr. G. Greville Williams for the pathological reports.

\section{REFERENCES}

American Rheumatism Association (1959). Diagnostic criteria for rheumatoid arthritis: 1958 revision. Ann. rheum. Dis., 18, 49.

Bagratuni, L. (1956). Anarthritic rheumatoid disease. Lancet, 2, 694.

Ball, J. (1955). Differential agglutination test in rheumatoid arthritis complicated by pneumoconiosis. Ann. rheum. Dis., 14, 159.

- and Lawrence, J. S. (1961). Epidemiology of the sheep cell agglutination test. Ibid., 20, 235.

Brinkman, G. L., and Chaikof, L. (1959). Rheumatoid lung disease: report of a case which developed in childhood. Amer. Rev. resp. Dis., 80, 732.

Campbell, E. J. M., and Howell, J. B. L. (1960). Simple rapid methods of estimating arterial and mixed venous $\mathrm{pCO}_{2}$. Brit. med. J., 1, 458.

Caplan, A. (1953). Certain unusual radiological appearances in the chest of coal-miners suffering from rheumatoid arthritis. Thorax, $8,29$.

(1959). Rheumatoid disease and pneumoconiosis (Caplan's syndrome). Proc. roy. Soc. Med., 52, 1111.

Christie, G. S. (1954). Pulmonary lesions in rheumatoid arthritis. Aust. Ann. Med., 3, 49

Cudkowicz, L., Madoff, I. M., and Abelmann, W. H. (1961). Rheumatoid lung disease. A case report which includes respiratory toid lung disease. A case report which includes respiratory

Dixon, A. St. J., and Ball, J. (1957). Honeycomb lung and chronic rheumatoid arthritis. Ann. rheum. Dis., 16, 241.

Ellman, P., and Ball, R. E. (1948). 'Rheumatoid disease' with joint and pulmonary manifestations. Brit. med. J., 2, 816.

Emerson, P. A. (1956). Pleural effusion complicating rheumatoid arthritis. Ibid., 1, 428

Gardner, D. L., Duthie, J. J. R., Macleod. J., and Allan, W. S. A. (1957). Pulmonary hypertension in rheumatoid arthritis: report of a case with intimal sclerosis of the pulmonary and digital arteries. Scot. med. J., 2, 183.
Gresham, G. A., and Kellaway, T. D. (1958). Rheumatoid disease in $\overline{\bar{N}}$ the larynx and lung. Ann. rheum. Dis., 17, 286.

Hamman, L., and Rich, A. R. (1944). Acute diffuse interstitial fibrosis of the lungs. Bull. Johns Hopk. Hosp., 74, 177.

Hart, F. Dudley, and Mackenzie, D. H. (1955). Pulmonary rheuma- $-\frac{O}{\bar{N}}$ toid disease. Brit. med. J., 2, 890

Heppleston, A. G. (1956). The pathology of honeycomb lung. Thorax, $11,77$.

Horler, A. R., and Thompson, M. (1959). The pleural and pulmonary complications of rheumatoid arthritis. Ann. int. Med. 51, 1179 .

Kellgren, J. H., and Ball, J. (1959). Clinical significance of the rheumatoid serum factor. Brit. med. J., 1, 523.

Mason, R. M., and Steinberg, V. L. (1958). Systemic manifestations:of rheumatoid arthritis and the pararheumatic diseases. IIRheumatoid arthritis. Ann. phys. Med., 4, 265.

Miall, W. E. (1955). Rheumatoid arthritis in males; an epidemiological study of a Welsh mining community. Ann. rheum. dis., 14,150 .

Ognibene, A. J. (1960). Systemic 'theumatoid disease' with inter-? stitial pulmonary fibrosis. Arch, intern. Med., 105, 762.

Oswald, N., and Parkinson, T. (1949). Honeycomb lungs. Quart. J. Med., N.S., 18, 1 . Price, T. M. L., and Skelton, M. O. (1956). Rheumatoid arthritis $v$

Rubin, E. H., and Lubliner, R. (1957). The Hamman-Rich syndrome :O review of the literature and analysis of 15 cases. Medicine (Baltimore), 36, 397.

Scadding, J. G. (1960). Chronic diffuse interstitial fibrosis of the lungs. $\vec{c}$ Brit. med. J., 1, 443.

Smith, W. W., and Rothermich, N. O. (1957). Diffuse interstitial כ. fibrosis complicating rheumatoid arthritis: report of a case. Ohio State med. J., 53, 773.

Ward, R. (1961). Pleural effusion and rheumatoid disease. Lancet, 2, 1336.

\section{ADDENDUM}

Since this paper was prepared, Dr. F. I. Lee and Dr. A. T. Brain (Lancet, 1962, 2, 693) have described three patients who had chronic inter-๊ stitial fibrosis of the lungs and later developed $\stackrel{\mathbb{\perp}}{\circ}$ rheumatoid arthritis. They concluded that diffuse $\vec{\overrightarrow{ }}$ pulmonary fibrosis may sometimes be a manifesta- 3 tion of rheumatoid disease even in the absence of $\vec{\partial}$ overt arthritis. 